\title{
Design and Synthesis of a 3,2'-Indane]-1',3'-Dione Derivative and Their Theoretical Interaction with the Coronavirus Surface (COVID-19)
}

\author{
Rosas-Nexticapa Marcela ${ }^{1}\left(\mathbb{D}\right.$, Figueroa-Valverde Lauro ${ }^{2, *}{ }^{\mathbb{D}}$, Díaz-Cedillo Francisco ${ }^{3}{ }^{\mathbb{D}}$, López-Ramos \\ Maria ${ }^{1, *}{ }^{(\mathbb{D})}$, Mateu-Armad Maria Virginia ${ }^{1(\mathbb{D})}$, Garcimarrero E. Alejandara ${ }^{4}(\mathbb{D})$, Alvarez-Ramirez Ma. \\ Magdalena $^{1}$ (D), Lopez-Gutierrez Tomas ${ }^{2}$ (D) , Cauich-Carrillo Regina ${ }^{1}$ (D) \\ 1 Facultad de Nutrición, Universidad Veracruzana, Médicos y Odontologos s/n C.P. 91010, Unidad del Bosque Xalapa \\ Veracruz, México \\ 2 Laboratory of Pharmaco-Chemistry, Faculty of Chemical Biological Sciences, University Autonomous of Campeche, Av. \\ Agustín Melgar s/n, Col Buenavista C.P. 24039 Campeche, Camp., México \\ 3 Escuela Nacional de Ciencias Biológicas del Instituto Politécnico Nacional. Prol. Carpio y Plan de Ayala s/n Col. Santo \\ Tomas, D.F. C.P. 11340, México \\ 4 Facultad de Medicina, Universidad Veracruzana, Médicos y Odontologos s/n C.P. 91010, Unidad del Bosque Xalapa \\ Veracruz, México \\ * Correspondence: 1figuero@uacam.mx (F.V.L); maclopez@uacam.mx (R.N.M);
}

Received: 12.07.2020; Revised: 27.08.2020; Accepted: 29.08.2020; Published: 1.09.2020

Abstract: Several drugs have been used for the treatment of coronavirus disease (COVID-19); however, these drugs have not produced any effect against COVID-19. In the search of a clinical alternative, the aim of this research was to synthetize a 3,2'-indane]-1',3'-dione (compound 6) from 2,4Dinitrophenyl hydrazine to evaluate their interaction with COVID-19 (6UL7) using either chloroquine and remdesivir as controls in a theoretical model. The results showed that compound 6 have a different affinity by 6UL7-protein surface compared with either chloroquine and remdesivir. In addition, other data showed low binding energy for 6 compared with both hydroxychloroquine and remdesivir. In conclusion, this phenomenon suggests that compound 6 could exert some change in the biological activity of COVID-19.

Keywords: 3,2'-indane]-1',3'-dione; coronavirus; hydroxychloroquine; remdesivir.

(C) 2020 by the authors. This article is an open-access article distributed under the terms and conditions of the Creative Commons Attribution (CC BY) license (https://creativecommons.org/licenses/by/4.0/).

\section{Introduction}

One of the main problems worldwide are respiratory diseases; these clinical pathologies can be caused by various pathogens such as coronavirus [1-4]. Some drugs have been used to try to control the severe acute respiratory syndrome coronavirus (SARS-CoV) such as ribavirin, interferon (IFN)- $\alpha /$ mycophenolic acid [5], ritonavir/ lopinavir [6], chloroquine [7]; however, these drugs have shown little or no effectiveness against SARS-CoV. In search of some therapeutic alternative, different compounds have been developed; for example, the synthesis of compound TG-0205221 from L-glutamic acid as a SARS-CoV-protease inhibitor [8]. Other data showed the preparation of a series of $\alpha$-ketoamides from a glutamine derivative with antiviral activity against SARS-CoV [9]. In addition, a Glycyrrhizin derivative was synthesized via reaction of L-leucine-tert-butyl or L-glutamic acid dibenzyl ester hydrochlorides with Glycyrrhizin for treatment of SARS-CoV [10]. Another study showed the preparation of a 
series of dihydropyrimidine derivatives from benzaldehyde, ethylcyanoacetate, and thiourea as SARS-COV inhibitors [11]. Recently, some steroid derivatives have prepared from 3ethylinaniline to evaluate their theoretical activity against SARS-CoV [12]. All these data indicate that several compounds can exert antiviral activity on some virus strain; however, the interaction with the virus surface is very confusing; perhaps this phenomenon could be due to their different chemical structures. Analyzing all these data, this research aimed to synthesize a new 3,2'-indane]-1',3'-dione from (2,4-Dinitro-phenyl)-hydrazine to evaluate their interaction with 6UL7 protein surface using a docking model.

\section{Materials and Methods}

The compounds used in this research were acquired from Sigma-Aldrich Co., Ltd. The melting point for compounds was evaluated on an Electrothermal (900 model). Infrared spectra (IR) were evaluated with a Thermo Scientific iSOFT-IR spectrometer.1H, and 13C NMR spectra were determined using a Varian VXR300/5 FT NMR spectrometer at $300 \mathrm{MHz}$ in $\mathrm{CDCl} 3$ using TMS as the internal standard. EIMS spectra were obtained with a Finnigan Trace Gas Chromatography Polaris Q-Spectrometer. Elementary analysis data were acquired from a Perkin Elmer Ser. II CHNS/02400 elemental analyzer.

\subsection{Synthesis of 1-[(E)-[(2,4-dinitrophenyl)hydrazono]methyl]naphthalen-2-ol (2).}

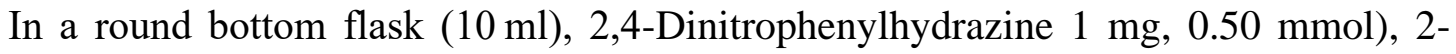
Hydroxy-naphthalene-1-carbaldehyde ( $86 \mathrm{mg} .0 .5 \mathrm{mmol}$ ), boric acid (30 mg, 0.48), and methanol $(5 \mathrm{ml})$ were stirred at room temperature for $72 \mathrm{~h}$. Then, the solvent was evaporated under reduced pressure and following the product was purified via crystallization using the methanol:hexane:water (4:1:1) system; yielding $65 \%$ of product; m.p. 150-152 oC; IR (Vmax, cm-1) 3400, 3320, 3310, and 1512: ${ }^{1} \mathrm{H}$ NMR (300 MHz, CDCl3-d) $\delta H: ~ 6.22 ~(m, 1 H), 6.88-$ $7.92(\mathrm{~m}, 4 \mathrm{H}), 7.98(\mathrm{~m}, 1 \mathrm{H}), 8.30-8.50(\mathrm{~m}, 2 \mathrm{H}), 8.56(\mathrm{~m}, 1 \mathrm{H}), 8.80(\mathrm{~m}, 1 \mathrm{H}), 9.36(\mathrm{~m}, 1 \mathrm{H}), 12.92$ (broad, 2H) ppm. ${ }^{13} \mathrm{C}$ NMR $(300 \mathrm{~Hz}, \mathrm{CDCl} 3){ }^{13} \mathrm{C}: 104.32,112.20,120.82,122.74,123.50$, $124.68,126.40,126.80,128.64,130.66,131.05,133.11,135.75,136.00,143.26,146.50$, 160.60 ppm. EI-MS m/z: 352.08. Anal. Calcd. for C17H12N4O5: C, 57.96; H, 3.43; N, 15.90; O, 22.71. Found: C, 57.93; H, 3.41.

2.2. 6-[(2E)-2-[(2-hydroxy-1-naphthyl)methylene]hydrazino]spiro[2,4-dioxabicyclo[3.3.1]nona-1(8),5(9),6-triene-3,2'-indane ]-1',3'-dione (3).

In a round bottom flask $(10 \mathrm{ml})$, compound $2(200 \mathrm{mg}, 0.56 \mathrm{mmol})$, ninhydrin $(90 \mathrm{mg}$. $0.56 \mathrm{mmol}$ ), potassium carbonate $(60 \mathrm{mg}, 0.43 \mathrm{mmol})$, and $5 \mathrm{ml}$ of dimethyl sulfoxide were stirred at reflux for $12 \mathrm{~h}$. Then, the solvent was evaporated under reduced pressure and following the product was purified via crystallization using the methanol:water (4:1) system; yielding 54\% of product; m.p. 88-90 ${ }^{\circ} \mathrm{C}$; IR $\left(V_{\max }, \mathrm{cm}^{-1}\right) 3400,4422,3310,1622$ and 1282: ${ }^{1} \mathrm{H}$ NMR (300 MHz, $\left.\mathrm{CDCl}_{3}-d\right) \delta \mathrm{H}: 6.22(\mathrm{~m}, 1 \mathrm{H}), 6.88(\mathrm{~m}, 1 \mathrm{H}), 7.30-7.40(\mathrm{~m}, 2 \mathrm{H}), 7.66-7.92(\mathrm{~m}$, $3 \mathrm{H}), 8.04-8.20(\mathrm{~m}, 4 \mathrm{H}), 8.30-8.50(\mathrm{~m}, 2 \mathrm{H}), 8.80(\mathrm{~m}, 1 \mathrm{H}), 12.12$ (broad, $2 \mathrm{H})$ ppm. ${ }^{13} \mathrm{C} \mathrm{NMR}$ $\left(300 \mathrm{~Hz}, \mathrm{CDCl}_{3}\right) \delta \mathrm{c}: 74.62,99.40,106.80,108.26,116.72,120.86,122.72,123.50,126.00$, 126.82 , 128.62, 129.16, 130.62, 131.04, 134.60, 136.00, 138.16, 141.12, 146.50, 147.02, 160.60, 184.56, 188.60 ppm. EI-MS m/z: 436.10. Anal. Calcd. for $\mathrm{C}_{26} \mathrm{H}_{16} \mathrm{~N}_{2} \mathrm{O}$ 5: C, 71.56; H, $3.70 ; \mathrm{N}, 6.42 ; \mathrm{O}, 18.33$. Found: C, 71.53; H, 3.68. 
2.3. [1-[(E)-[(1',3'-dioxospiro[2,4-dioxabicyclo[3.3.1]nona-1(8),5(9),6-triene-3,2'-indane]-6yl)hydrazono]methyl]-2-naphthyl] hex-5-ynoate (4).

In a round bottom flask $(10 \mathrm{ml})$, compound $3(200 \mathrm{mg}, 0.46 \mathrm{mmol}), 5$-hexynoic acid (100 $\mu 1,0.90 \mathrm{mmol})$, boric acid (30 $\mathrm{mg}, 0.48)$, and $5 \mathrm{~mL}$ of methanol were stirred at room temperature for $72 \mathrm{~h}$. Then, the solvent was evaporated under reduced pressure and following the product was purified via crystallization using the methanol:hexane:water (4:1:1) system; yielding 54\% of product; m.p. $78-80{ }^{\circ} \mathrm{C}$; IR $\left(V_{\max }, \mathrm{cm}^{-1}\right) 3310,2122,1622$ and 1280: yielding $45 \%$ of product; m.p. $126-128{ }^{\circ} \mathrm{C}$; IR $\left(V_{\max }, \mathrm{cm}^{-1}\right) 3332,2240$ and $1312:{ }^{1} \mathrm{H}$ NMR $(300 \mathrm{MHz}$, $\left.\mathrm{CDCl}_{3}-d\right) \delta_{\mathrm{H}}: 1.62(\mathrm{~m}, 2 \mathrm{H}), 2.08(\mathrm{~s}, 1 \mathrm{H}), 2.30-2.32(\mathrm{~m}, 2 \mathrm{H}), 2.52(\mathrm{~m}, 2 \mathrm{H}), 6.28(\mathrm{~m}, 1 \mathrm{H}), 7.30$ (m, 1H), $7.32(\mathrm{~m}, 1 \mathrm{H}), 7.38(\mathrm{~m}, 1 \mathrm{H}), 7.40(\mathrm{~m}, 1 \mathrm{H}), 7.56-7.78(\mathrm{~m}, 2 \mathrm{H}), 8.04(\mathrm{~m}, 2 \mathrm{H}), 8.08(\mathrm{~m}$, $1 \mathrm{H}), 8.20(\mathrm{~m}, 2 \mathrm{H}), 8.76(\mathrm{~m}, 1 \mathrm{H}), 9.12(\mathrm{~m}, 1 \mathrm{H}), 11.72(\mathrm{broad}, 1 \mathrm{H}) \mathrm{ppm} .{ }^{13} \mathrm{C}$ NMR $(300 \mathrm{~Hz}$, $\left.\mathrm{CDCl}_{3}\right) \delta_{\mathrm{C}}: 17.82,23.62,33.20,69.12,74.62,83.21,99.40,108.25,116.56,116.74,122.54$, $125.09,126.00,126.28,126.92,128.08,128.92,130.16,131.32,133.50,134.60,138.22$, 141.12. 147.02, 149.04. 151.40, 169.86, 184.56, 186.60 ppm. EI-MS m/z: 530.14. Anal. Calcd. for $\mathrm{C}_{32} \mathrm{H}_{22} \mathrm{~N}_{2} \mathrm{O}_{6}$ : C, 72.45; H, 4.18; N, 5.28; O, 18.09. Found: C, 72.42; H, 4.16.

2.4. [1-[(E)-[(1',3'-dioxospiro[2,4-dioxabicyclo[3.3.1]nona-1(8),5(9),6-triene-3,2'-indane]-6yl)hydrazono]methyl]-2-naphthyl] 6-(2-aminoethylamino)hex-5-ynoate (5).

In a round bottom flask $(10 \mathrm{ml})$, compound $4(200 \mathrm{mg}, 0.38 \mathrm{mmol})$, ethylenediamine (50 $\mu \mathrm{l}, 0.82 \mathrm{mmol})$ and Copper(II) chloride anhydrous (60 mg, $0.44 \mathrm{mmol})$ and $5 \mathrm{ml}$ of methanol were stirred at room temperature for $72 \mathrm{~h}$. Then, the solvent was evaporated under reduced pressure and following the product was purified via crystallization using the methanol:water (4:1) system; yielding $52 \%$ of product; m.p. $112-114{ }^{\circ} \mathrm{C}$; IR $\left(V_{\max }, \mathrm{cm}^{-1}\right) 3310$, 2120, 1622 and 1282: ${ }^{1} \mathrm{H}$ NMR $\left(300 \mathrm{MHz}, \mathrm{CDCl}_{3}-d\right) \delta_{\mathrm{H}}: 1.70-2.52(\mathrm{~m}, 6 \mathrm{H}), 2.68-2.90(\mathrm{~m}, 4 \mathrm{H})$, 5.38 (broad, 4H), $6.22(\mathrm{~m}, 1 \mathrm{H}), 7.30(\mathrm{~m}, 1 \mathrm{H}), 7.32(\mathrm{~m}, 1 \mathrm{H}), 7.38(\mathrm{~m}, 1 \mathrm{H}), 7.40(\mathrm{~m}, 1 \mathrm{H}), 7.56-$ $7.78(\mathrm{~m}, 2 \mathrm{H}), 8.04(\mathrm{~m}, 2 \mathrm{H}), 8.08(\mathrm{~m}, 1 \mathrm{H}), 8.20(\mathrm{~m}, 2 \mathrm{H}), 8.76(\mathrm{~m}, 1 \mathrm{H}), 9.12(\mathrm{~m}, 1 \mathrm{H}) \mathrm{ppm} .{ }^{13} \mathrm{C}$ NMR $\left(300 \mathrm{~Hz}, \mathrm{CDCl}_{3}\right) \delta_{\mathrm{C}}: 16.44,23,36,33.22,40.92,55.44,74.62,77.24,87.30,99.40$, 108.26 , 116.54, 116.75, 122.50, 125.09, 126.00, 126.26, 126.92, 128.08, 128.92, 130.16, 131.34, 133.50, 134.60, 138.20, 141.12, 147.02, 149.04, 151.40, 169.90, 184.56, 186.60 ppm. EI-MS m/z: 588.20. Anal. Calcd. for $\mathrm{C}_{34} \mathrm{H}_{28} \mathrm{~N}_{4} \mathrm{O}_{6}$ : C, 69.38; H, 4.79; N, 9.52; O, 16.31. Found: C, 39.35; H, 4.76.

2.5. 6-[(2E)-2-[[2-[[(4E)-1,4-diazacyclodec-4-en-9-yn-5-yl]oxy]-1-naphthyl]methylene]hydrazino]spiro[2,4-dioxabicyclo[3.3.1]nona-1(8),5(9),6-triene-3,2'-indane]-1',3'-dione (6).

In a round bottom flask $(10 \mathrm{ml})$, compound $5(200 \mathrm{mg}, 0.34 \mathrm{mmol})$, boric acid (30 $\mathrm{mg}$, 0.48), and $5 \mathrm{~mL}$ of methanol were stirred at room temperature for $72 \mathrm{~h}$. Then, the solvent was evaporated under reduced pressure and following the product was purified via crystallization using the methanol:water (4:1) system; yielding $52 \%$ of product; m.p. $172-174{ }^{\circ} \mathrm{C}$; IR ( $V_{\max }$, $\left.\mathrm{cm}^{-1}\right) 3330,3310,2122,1280$ and 1222: ${ }^{1} \mathrm{H}$ NMR $\left(300 \mathrm{MHz}, \mathrm{CDCl}_{3}-d\right) \delta_{\mathrm{H}}: 1.52-3.70(\mathrm{~m}, 10 \mathrm{H})$, $6.26(\mathrm{~m}, 1 \mathrm{H}), 7.22(\mathrm{~m}, 1 \mathrm{H}), 7.30-7.40(\mathrm{~m}, 2 \mathrm{H}), 7.60-7.92(\mathrm{~m}, 3 \mathrm{H}), 8.04(\mathrm{~m}, 2 \mathrm{H}), 8.10(\mathrm{~m}, 1 \mathrm{H})$, $8.20(\mathrm{~m}, 2 \mathrm{H}), 8.70(\mathrm{~m}, 1 \mathrm{H}), 8.94(\mathrm{~m}, 1 \mathrm{H}), 10.94$ (broad, $2 \mathrm{H}) \mathrm{ppm} .{ }^{13} \mathrm{C} \mathrm{NMR}\left(300 \mathrm{~Hz}, \mathrm{CDCl}_{3}\right)$ $\delta_{\mathrm{C}}: 18.40,25.62,35.11,51.63,52.22,74.62,81.80,89.26,99.40,108.26,114.86,116.72$, $121.16,122.64,124.83,126.00,127.56,129.09,129.40,131.12,132.00,132.12,134.60$, 138.16, 141.12, 145.36, 147.02, 154.46, 165.66, 184.56, 186.60 ppm. EI-MS m/z: 570.19. Anal. Calcd. for $\mathrm{C}_{34} \mathrm{H}_{26} \mathrm{~N}_{4} \mathrm{O}$ : $\mathrm{C}, 71.57 ; \mathrm{H}, 4.59 ; \mathrm{N}, 9.82 ; \mathrm{O}, 14.02$. Found: C, 71.54; H, 4.56. 


\subsection{Pharmacophore evaluation.}

The 3D pharmacophore model for the compounds 6 was determined using LigandScout software $[13,14]$.

\subsection{Theoretical asses of compound 2 to 6 with coronavirus SAR-COV19 (6LU7 protein).}

The interaction of compound 6 with 6LU7 protein surface [15] was carried out using both hydroxychloroquine and remdesivir as controls in a DockingServer software [16].

\subsection{Theoretical pharmacokinetic properties}

Some physicochemical parameters of compounds 2-4 were determined to determine the oral availability of the drug and its pharmacokinetic properties using SwissADME software [17].

\section{Results and Discussion}

For several years, some compounds have been developed for the treatment of virus strains using expensive reagents, which require special conditions. Besides, the interaction of these compounds with the virus surface is confusing. In this way, in this study, two new 3,2'indane]-1',3'-dione were prepared to evaluate their interaction with 6LU7 protein surface using a docking model as follows:

\subsection{Chemicals synthesis.}

\subsubsection{Synthesis of an imino derivative.}

Several imino analogs have been prepared using some reagents such as gold [18, 19], Trimethylsilylmethyl Triflate [20], NaOMe [21], vinyl azide derivatives [22], Benzofurazan $\mathrm{N}$-oxides [23], $\mathrm{I}_{2} / \mathrm{K}_{2} \mathrm{CO}_{3}$ [24], and others. In this study, an imino derivative was prepared from 2,4-Dinitrophenylhydrazine and 2-Hydroxy-naphthalene-1-carbaldehyde in the presence of boric acid to form compound 2 (Figure 1). The ${ }^{1} \mathrm{H}$ NMR spectrum from 2 showed several signals at 6.88-7.92 and 8.30-8.50 ppm for naphthalene; at 7.98, 8.56, and 9.36 ppm for phenyl bound to both ether groups; at $8.80 \mathrm{ppm}$ for imino group; at 12.92 for the amino group. ${ }^{13} \mathrm{C}$ NMR spectra showed chemical shifts at 104.32, 120.85-123.50, 126.83-131.07, 136.00, and $160.60 \mathrm{ppm}$ for naphthalene fragment; at 112.16, 124.66-126.40, 133.76-135.75 and 143.32 ppm for phenyl bound to both ether groups; at $146.50 \mathrm{ppm}$ for imino group. Besides, the mass spectrum from 2 showed a molecular ion $(\mathrm{m} / \mathrm{z}) 352.08$.

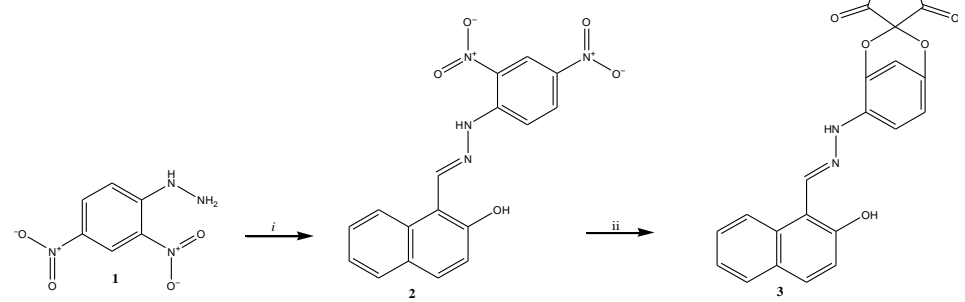

Figure 1. Synthesis of 6-[(2E)-2-[(2-hydroxy-1-naphthyl)methylene]hydrazino]spiro[2,4-dioxabicyclo[3.3.1]nona-1(8),5(9),6-triene-3,2'-indane]-1',3'-dione (3). Reagents and Conditions: $i=2$-Hydroxy-naphthalene-1carbaldehyde, boric acid, room temperature, $72 \mathrm{~h}$; $i i=$ ninhydrin, potassium carbonate, dimethyl sulfoxide, reflux, $12 \mathrm{~h}$. 


\subsubsection{Etherification reaction}

There several reagents used for etherification reactions using some reagents such as Isonicotinate ester [25], palladium [26], tert-Butyl Nitrite [27], Ceric Ammonium Nitrate [28]. In addition, some reports showed the preparation of ether derivatives through of displacement of the nitro group using dipolar aprotic solvents such as dimethyl sulfoxide [29] In this way, in this research, an ether derivative (3) was prepared from compound 2, dimethyl sulfoxide and potassium carbonate (Figure 1). The ${ }^{1} \mathrm{H}$ NMR spectrum from 3 showed several signals at 6.22 , 7.30-7.40 ppm for phenyl group bound to both ether groups; at 6.88, 7.66-7.92 and 8.30-8.50 ppm for naphthalene fragment; at 8.04-8.20 ppm for Indan-1,3-dione fragment; at $8.80 \mathrm{ppm}$ for the imino group; at $12.12 \mathrm{ppm}$ for both hydroxyl and amino groups. ${ }^{13} \mathrm{C}$ NMR spectra showed chemical shifts at 74.62, 126.00, 134.60 and $138.10 \mathrm{ppm}$ for Indan-1,3-dione fragment; at $99.40,108.26-116.72,129.16,141.12$ and $147.02 \mathrm{ppm}$ for phenyl bound to both ether groups; at $106.80,120.86-123.50,126.82,130.62-131.04,136.00$ and $160.60 \mathrm{ppm}$ for naphthalene fragment; at $146.50 \mathrm{ppm}$ for imino group; at 184.56-188.60 ppm for ketone groups. Finally, the mass spectrum from 3 showed a molecular ion $(\mathrm{m} / \mathrm{z}) 436.10$.

\subsubsection{Esterification reaction}

Different reagents have been used to produce ester derivatives; however, most of the conventional methods require special conditions [30-33]. Analyzing these data, in this investigation, a previously method reported [34] for esterification of some ester derivatives was used. In this way, the compound 4 was prepared via reaction 3 with succinic acid using boric acid as a catalyst (Figure 2).

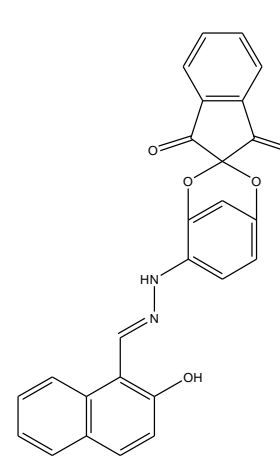

3
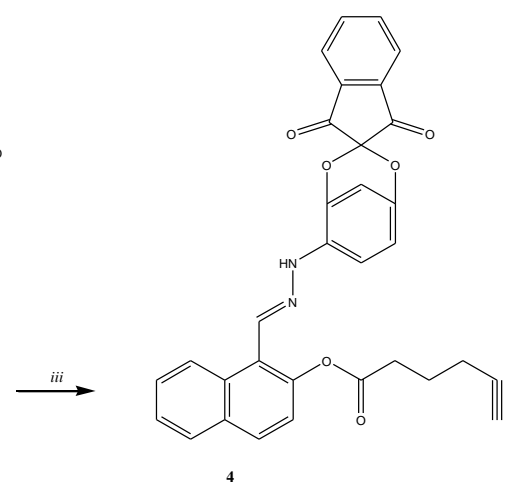
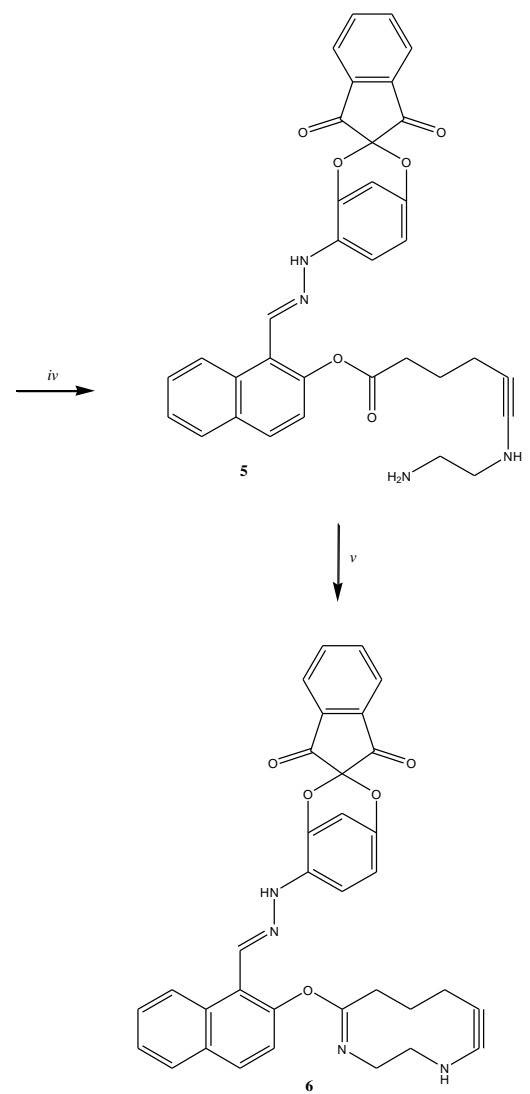

Figure 2. Synthesis of an Indane-1',3'-dione derivative (6). Reagents and Conditions: iii =5-hexanoic acid, boric acid, room temperature, $72 \mathrm{~h} ; i v=$ ethylenediamine, Copper(II) chloride, room temperature, $72 \mathrm{~h} ; v=$ boric acid, room temperature $72 \mathrm{~h}$. 
The ${ }^{1} \mathrm{H}$ NMR spectrum from 4 showed several signals at 1.62 and $2.30-2.52 \mathrm{ppm}$ for methylene groups bound to both ester and alkyne groups; at $2.08 \mathrm{ppm}$ for alkyne group; at 6.28 , 7.32 and $7.40 \mathrm{ppm}$ for phenyl bound o both ether groups; at 7.30, 7.38, 7.56-7.78, 8.08 and $8.76 \mathrm{ppm}$ for naphthalene fragment; at 8.04 and $8.30 \mathrm{ppm}$ for Indan-1,3-dione fragment; at 9.12 ppm for imino group; at $11.72 \mathrm{ppm}$ for amino group. ${ }^{13} \mathrm{C}$ NMR spectra showed chemical shifts at $17.82-33.20 \mathrm{ppm}$ for methylene groups bound to both ester and alkyne groups; at 69.12 and $83.21 \mathrm{ppm}$ for alkyne group; at 74.62, 126.00 and 134.60-138.22 ppm for Indan-1,3-dione fragment; at 99.40-108.25, 116.74-128.92 and 141.12-147.02 ppm for phenyl bound to both ether groups; at 116.56, 122.54-125.09, 126.28-128.08, 130.16-135.50 and 149.04 ppm for naphthalene fragment; at $151.40 \mathrm{ppm}$ for imino group; at $169.86 \mathrm{ppm}$ fo ester group; at 184.56 $186.60 \mathrm{ppm}$ for ketone groups. In addition, the mass spectrum from 4 showed a molecular ion $(\mathrm{m} / \mathrm{z}) 530.14$.

\subsubsection{Addition reaction.}

The addition reaction of amino to the alkyne, has been reported using some protocols that involve a series of reagents such as $\mathrm{Pd}\left(\mathrm{CH}_{3} \mathrm{CN}\right)_{4}\left(\mathrm{BF}_{4}\right)_{2}$ [35], $\mathrm{Pd}(\mathrm{OAc})_{2}$ [36], $\mathrm{CuBr}_{2}$ [37], gold(III) [38], acetonitrile, $\mathrm{K}_{2} \mathrm{CO}_{3}$ [39] and others. In this research, 4 reacted with ethylenediamine in the presence of Copper(II) chloride to form compound 5. The ${ }^{1} \mathrm{H}$ NMR spectrum from 5 showed several signals at 1.70-2.52 ppm for methylene groups bound to both ester and alkyne groups; at 2.68-2.90 ppm for methylene groups bound to both amino groups; at $5.38 \mathrm{ppm}$ for amino groups; at $6.20,7.32$ and $7.40 \mathrm{ppm}$ for phenyl bound to both ether groups; at 7.30, 7.38, 7.56-7.78, 8.06 and $8.76 \mathrm{ppm}$ for naphthalene fragment; at 8.04 and 8.20 ppm for Indan-1,3-dione fragment; at $9.12 \mathrm{ppm}$ for imino group. ${ }^{13} \mathrm{C}$ NMR spectra showed chemical shifts at 16.94-33.22 ppm for methylene groups bound to both ester and alkyne groups; at 40.92-55.44 for methylene groups bound to both amino groups; at 74.62, 126.00 and 134.60-138.20 ppm for Indan-1,3-dione fragment; at 77.24-87.30 ppm for alkyne group; at 99.40-108.26, 116.78, 128.92 and 141.12-147.02 ppm for phenyl bound to both ether groups; at $116.54,122.50,126.26-128.08,130.16-133.50$ and $149.04 \mathrm{ppm}$ for naphthalene fragment; at $151.40 \mathrm{ppm}$ for imino group; at $169.90 \mathrm{ppm}$ for ester group; at $184.56-186.60 \mathrm{ppm}$ for ketone groups. Besides, the mass spectrum from 5 showed a molecular ion $(\mathrm{m} / \mathrm{z}) 588.20$.

\subsubsection{Synthesis of an Indane-1',3'-dione derivative.}

Finally, compound 6 was prepared via intramolecular reaction between both carbonyl and amino groups involved in the chemical structure of 5 using boric acid as a catalyst. The ${ }^{1} \mathrm{H}$ NMR spectrum from 6 showed several signals at $1.52-3.70 \mathrm{ppm}$ for methylene groups of (4Z)1,4-diazacyclodec-4-en-9-yne system; at 6.26 and 7.30-7.40 ppm for phenyl bound to both ether groups; at 7.22, 7.60-7.92, 8.10 and $8.70 \mathrm{ppm}$ for naphthalene fragment; at 8.04 and 8.20 for Indan-1,3-dione fragment; at $8.94 \mathrm{ppm}$ for imino group; at $10.94 \mathrm{ppm}$ for amino groups. ${ }^{13} \mathrm{C}$ NMR spectra showed chemical shifts at 18.40-52.22 and $165.66 \mathrm{ppm}$ for (4Z)-1,4diazacyclodec-4-en-9-yne system; at 74.62, 126.00 and 134.60-138.16 ppm for Indan-1,3dione fragment; at 81.80-89.26 ppm for alkyne group; at 99.40-108.26, 116.72, 129.09, 141.12 and $147.02 \mathrm{ppm}$ for phenyl bound to both ester groups; at 114.86, 121.16-124.83, 127.56, 129.40-132.12 and $154.46 \mathrm{ppm}$ for naphthalene fragment; at $145.36 \mathrm{ppm}$ for imino group; at 184.56-186.60 ppm for ketone groups. Additionally, the mass spectrum from 6 showed a molecular ion $(\mathrm{m} / \mathrm{z}) 570.19$. 
3.1.6. Pharmacophore ligand model.

Several theoretical methods to evaluate the three-dimensional orientation adopted by several compounds have been used [12]; in this way, the use of a pharmacophore model is used to design novel drugs that can enhance or inhibit the function of some biological molecules. Analyzing these data, in this research, the LigandScout software [13, 14] was used to develop a pharmacophore model for compound 6 (Figures 3).

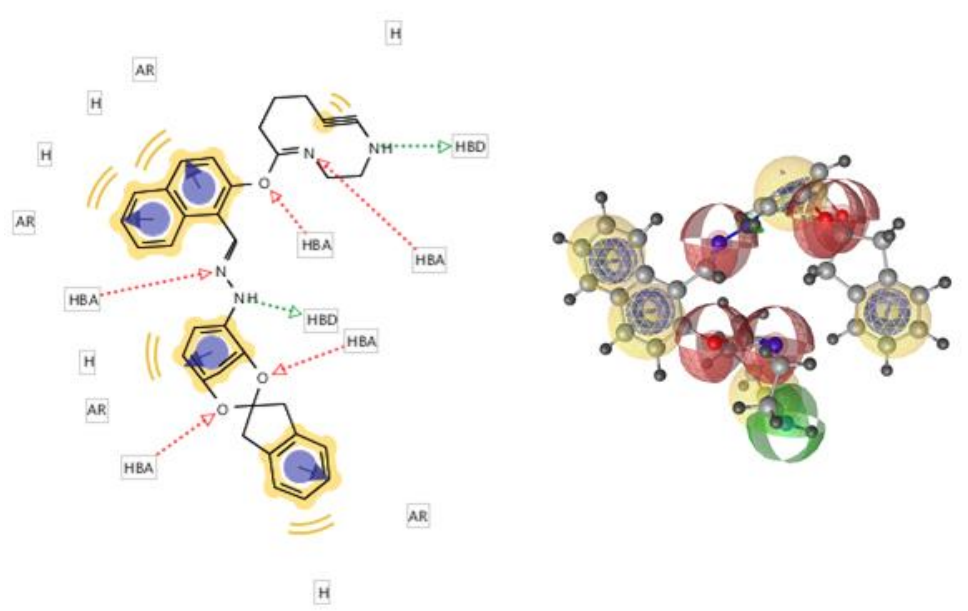

Figure 3. Scheme representing a pharmacophore model from compound 6 using the LigandScout software. The model involves a hydrogen bond acceptor (HBA, red) and hydrogen bond donor (HBD, green).

The results showed that some functional groups could act as hydrogen bond acceptors and hydrogen-bond donors; These physicochemical parameters are important in the interaction between the compound and biomolecule surface (Table 1).

Table 1. Physicochemical properties of compound 6.

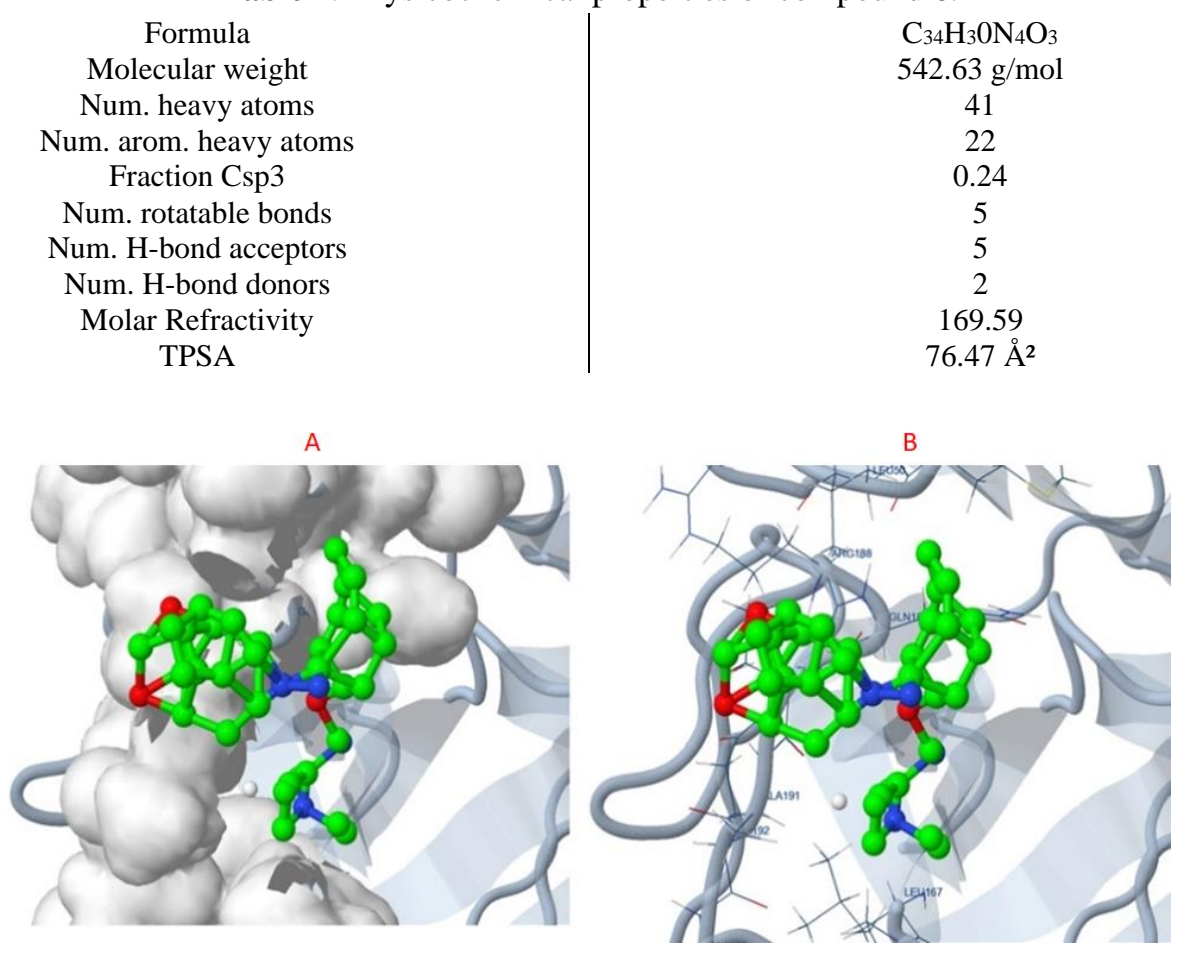

Figure 4. Interaction of compound 6 and the surface of the $6 \mathrm{LU} 7$ protein. Representations; $A=$ protein surface and the compound $6 ; \mathrm{B}=$ amino acid residues and the compound 6 . 


\subsubsection{Interaction protein-ligand.}

There are several reports to evaluate the theoretical interaction of some compounds with the protein surface using different theoretical models [40, 41]. In this way, a study was carried out on the interaction of compound 6 with coronavirus (6UL7 protein) using two antiviral drugs such as hydroxychloroquine and remdesivir [7, 42] as controls in the DockingServer software (Figure 4). The results showed differences in the interaction of either hydroxychloroquine, remdesivir, and compound 6 with 6LU7 protein surface (Table 2).

Table 2. Amino acid residues involved in the interaction of compound 6, remdesivir, and hydroxychloroquine with 6LU7 protein surface.

\begin{tabular}{|c|c|}
\hline Compound & Aminoacid residues \\
\hline 6 & $\begin{array}{c}\text { Leu50 } \\
\text { Pro168 } \\
\text { Thr } 190 \\
\text { Ala } 191 \\
\end{array}$ \\
\hline Remdesivir & $\begin{array}{c}\text { Leu }_{50} \\
\text { Met }_{165} \\
\text { Pro }_{168} \\
\text { Gln }_{189} \\
\text { Ala }_{191} \\
\text { Gln }_{192}\end{array}$ \\
\hline Hydroxychloroquine & $\begin{array}{l}\text { Ser }_{46} \\
\text { Leu}_{50} \\
\text { Pro168 }_{16} \\
\text { Gln }_{189}\end{array}$ \\
\hline
\end{tabular}

\subsubsection{Binding energy.}

To evaluate the binding energy involved in the interaction of compounds 6, hydroxychloroquine, and remdesivir, the DockingServer software was used. The results showed low binding energy for compound 6 compared with both compounds hydroxychloroquine and remdesivir (Table 3). this phenomenon could be due to differences in the chemical structure of each compound.

Table 3. Energy values of interaction between either hydroxychloroquine, remdesivir, and compound 6 with

\begin{tabular}{c|c|c|c|c|c} 
Compound & $\begin{array}{c}\text { Est. Free } \\
\text { Energy of } \\
\text { binding }\end{array}$ & $\begin{array}{c}\text { vdW + Hbond protein surface. } \\
+ \text { desolv energy }\end{array}$ & $\begin{array}{c}\text { Electrostatic } \\
\text { Energy }\end{array}$ & $\begin{array}{c}\text { Total Intramol. } \\
\text { Energy }\end{array}$ & $\begin{array}{c}\text { Interact } \\
\text { Surface }\end{array}$ \\
\hline 6 & -4.80 & -5.91 & 0.22 & -6.13 & 1119.53 \\
\hline Remdesivir & -1.54 & -4.29 & -0.03 & -4.23 & 609.11 \\
\hline Hydroxychloroquine & -3.36 & -5.49 & -0.33 & -5.83 & 608.27
\end{tabular}

Table 4. Pharmacokinetic parameters from compound 6.

GI absorption
BBB permeant
P-gp substrate
CYP1A2 inhibitor
CYP2C19 inhibitor
CYP2C9 inhibitor
CYP2D6 inhibitor
CYP3A4 inhibitor
Log $K_{\mathrm{p}}$ (skin permeation)

High
No
No
No
No
Yes
Yes
Yes
$-4.56 \mathrm{~cm} / \mathrm{s}$

3.1.9. Pharmacokinetic parameters.

There are studies to predict different pharmacokinetic parameters of several compounds [17]. In this research, some pharmacokinetic factors for compound 6 were evaluated using a 
SwissADME predictor model. The results showed that compound 6 could be absorbed via oral (Table 4); this phenomenon could also involve the interaction of some CyPs proteins in their metabolism.

\section{Conclusions}

In this study, facile synthesis of a new 1',3'-dione derivative (compound 6) from (2,4Dinitro-phenyl)-hydrazine was prepared using some chemical strategies. Besides, theoretical analysis of the interaction of 6 with 6LU7 protein surface showed that binding energy was lower compared with both hydroxychloroquine and remdesivir drugs. In conclusion, the new 1',3'-dione derivative could be an alternative therapeutic agent for the treatment of SARS$\mathrm{CoV}$.

\section{Funding}

This research received no external funding.

\section{Acknowledgments}

To Benjamin Valverde and Raquel Anzurez, for your unconditional support on this manuscript.

\section{Conflicts of Interest}

The authors declare no conflict of interest.

\section{References}

1. Wu, F.; Zhao, S.; Yu, B.; Chen, Y.; Wang, W.; Song, Z.G.; Yuan, M. A new coronavirus associated with human respiratory disease in China. Nature 2020, 579, 265-269, https://doi.org/10.1038/s41586-020-20083.

2. Lai, C.; Liu, Y.; Wang, C.; Wang, Y.; Hsueh, S.; Yen, M.; Hsueh, P. Asymptomatic carrier state, acute respiratory disease, and pneumonia due to severe acute respiratory syndrome coronavirus 2 (SARS-CoV-2): facts and myths. Journal of Microbiology, Immunology and Infection 2020, https://doi.org/10.1016/j.jmii.2020.02.012.

3. Chen, G.; Wu, D.; Guo, W.; Cao, Y.; Huang, D.; Wang, H.; Zhang, X. Clinical and immunological features of severe and moderate coronavirus disease 2019. The Journal of clinical investigation 2020, 130, https://doi.org/10.1172/JCI137244.

4. Zhang, J.; Zhou, L.; Yang, Y.; Peng, W.; Wang, W.; Chen, X. Therapeutic and triage strategies for 2019 novel coronavirus disease in fever clinics. The Lancet Respiratory Medicine 2020, 8, e11-e12, https://doi.org/10.1016/S2213-2600(20)30071-0.

5. Al-Osail, A.; Al-Wazzah, M. The history and epidemiology of Middle East respiratory syndrome corona virus. Multidisciplinary Respiratory Medicine 2017, 12, https://doi.org/10.1186/s40248-017-0101-8.

6. Lim, J.; Jeon, S.; Shin, H.; Kim, M.; Seong, Y.; Lee, W.; Park, S.; Choe, K.W.; Kang, Y.M.; Lee, B.Case of the index patient who caused tertiary transmission of coronavirus disease 2019 in Korea: The application of lopinavir/ritonavir for the treatment of COVID-19 pneumonia monitored by quantitative RT-PCR. Journal of Korean Medical Science 2020, 35, https://doi.org/10.3346/jkms.2020.35.e79.

7. Wang, M.; Cao, R.; Zhang, L.; Yang, X.; Liu, J.; Xu, M.; Shi, Z.; Hu, Z.; Zhong, W.; Xiao, G. Remdesivir and chloroquine effectively inhibit the recently emerged novel coronavirus (2019-nCoV) in vitro. Cell research 2020, 30, 269-271, https://doi.org/10.1038/s41422-020-0282-0.

8. $\quad$ Yang, S.; Chen, S.-J.; Hsu, M.-F.; Wu, J.-D.; Tseng, C.-T.K.; Liu, Y.-F.; Chen, H.-C.; Kuo, C.-W.; Wu, C.S.; Chang, L.-W.; Chen, W.-C.; Liao, S.-Y.; Chang, T.-Y.; Hung, H.-H.; Shr, H.-L.; Liu, C.-Y.; Huang, Y.A.; Chang, L.-Y.; Hsu, J.-C.; Peters, C.J.; Wang, A.H.J.; Hsu, M.-C. Synthesis, crystal structure, structureactivity relationships, and antiviral activity of a potent SARS coronavirus 3CL protease inhibitor. Journal of medicinal chemistry 2006, 49, 4971-4980, https://doi.org/10.1021/jm0603926.

9. Zhang, L.; Lin, D.; Kusov, Y.; Nian, Y.; Ma, Q.; Wang, J.; von Brunn, A.; Leyssen, P.; Lanko, K.; Neyts, J.; de Wilde, A.; Snijder, E.J.; Liu, H.; Hilgenfeld, R. $\alpha$-Ketoamides as broad-spectrum inhibitors of coronavirus and enterovirus replication: Structure-based design, synthesis, and activity assessment. Journal of medicinal chemistry 2020, 63, 4562-4578, https://doi.org/10.1021/acs.jmedchem.9b01828. 
10. Hoever, G.; Baltina, L.; Michaelis, M.; Kondratenko, R.; Baltina, L.; Tolstikov, G.; Cinatl, J. Antiviral Activity of Glycyrrhizic Acid Derivatives against SARS-Coronavirus. Journal of medicinal chemistry 2005, 48, 1256-1259, https://doi.org/10.1021/jm0493008.

11. Ramajayam, R.; Tan, K.; Liu, H.; Liang, P. Synthesis, docking studies, and evaluation of pyrimidines as inhibitors of SARS-CoV 3CL protease. Bioorganic \& medicinal chemistry letters 2010, 20, 3569-3572, https://doi.org/10.1016/j.bmcl.2010.04.118.

12. Figueroa-Valverde, L.; Díaz-Cedillo, F.; López-Ramos, M.; Rosas-Nexticapa, M.; Mateu-Armad, M.; Garcimarrero, E.; Cauich-Carrillo, R.; Ortiz-Ake, Y. Design and Synthesis of Five Cyclobuta-1,3-Dien-1yl-Steroid Derivatives to Evaluate Their Theoretical Activity Against COVID-19. Letters in Applied NanoBioScience 2020, 9, 1177-1187, https://doi.org/10.33263/LIANBS93.11771187.

13. Chiarelli, L.; Mori, M.; Barlocco, D.; Beretta, G.; Gelain, A.; Pini, E.; Lapillo, M. Discovery and development of novel salicylate synthase (MbtI) furanic inhibitors as antitubercular agents. European journal of medicinal chemistry 2018, 155, 754-763, https://doi.org/10.1016/j.ejmech.2018.06.033.

14. Valverde, L.; Lopez Ramos, M.; Diáz, F.; Rosas Nexticapa, M.; Virginia, M.; Alejandra, G.; Yaritza, B.Synthesis of two 7, 8-dioxabicyclo [4.1. 1] octan-3-yl)-steroid derivatives and evaluation of their inotropic activity in an animal model. Hacettepe Journal of Biology and Chemistry 2019, 48, 1-12, https://doi.org/10.15671/hjbc.602029.

15. Wolber, G.; Langer, T. LigandScout: 3-D pharmacophores derived from protein-bound ligands and their use as virtual screening filters. Journal of chemical information and modeling 2005, 45, 160-169, https://doi.org/10.1021/ci049885e.

16. Figueroa-Valverde, L.; Díaz-Cedillo, F.; Rosas-Nexticapa, M.; Mateu-Armand, V.; Pool-Gómez, E.; LopezRamos, M.; Hau-Heredia, L.; Alfonso-Jimenez, A.; Cabrera-Tuz J. Preparation of a steroid-oxazole-1,2'-[1, 3] oxazete] derivative: biological and theoretical evaluation of its interaction with a kinase protein (CK2). SN Applied Sciences 2019, 1, 361, https://doi.org/10.1007/s42452-019-0378-7.

17. Tripathi, P.; Ghosh, S.; Talapatra, S. Bioavailability prediction of phytochemicals present in Calotropis procera (Aiton) R. Br. by using Swiss-ADME tool. World Scientific News 2019, 131, 147-163.

18. Aguilar, E.; Santamaría, J. Gold-catalyzed heterocyclic syntheses through $\alpha$-imino gold carbene complexes as intermediates. Organic Chemistry Frontiers 2019, 6, 1513-1540, https://doi.org/10.1039/C9QO00243J.

19. Zeng, Z.; Jin, H.; Xie, J.; Tian, B.; Rudolph, M.; Rominger, F.; Hashmi, A. $\alpha$-Imino Gold Carbenes from 1, 2, 4-Oxadiazoles: Atom-Economical Access to Fully Substituted 4-Aminoimidazoles. Organic letters 2017, 19, 1020-1023, https://doi.org/10.1021/acs.orglett.7b00001.

20. Matsuo, K.; Matsuo, Y.; Iwashita, A.; Nakamura, E. Synthesis of Imino [60] fullerenes Using Nitriles and Trimethylsilylmethyl Triflate. Organic letters 2009, 11(18), 4192-4194, https://doi.org/10.1021/ol901851g.

21. Kurz, T.; Widyan, K. Efficient Conversion of O-Substituted 3-Hydroxy-4-imino-oxazolidin-2-ones into OSubstituted $\alpha$-Hydroxyamidoximes. Organic Letters 2004, 6, 4403-4405, https://doi.org/10.1021/ol040045v.

22. Liu, T.; Zhou, H.; Chen, P.; Huang, X.; Bao, L.; Zhuang, C.; Xu, H. Intramolecular Imino-ene Reaction of 2H-azirines with Alkenes: Rapid Construction of Spiro NH Aziridines from Vinyl Azides. Organic letters 2018, 20, 3156-3160, https://doi.org/10.1021/acs.orglett.8b00821.

23. Xu, W.; Chen, Y.; Wang, A.; Liu, Y. Benzofurazan N-Oxides as Mild Reagents for the Generation of $\alpha-$ Imino Gold Carbenes: Synthesis of Functionalized 7-Nitroindoles. Organic letters 2019, 21, 7613-7618, https://doi.org/10.1021/acs.orglett.9b02893.

24. Huang, Z.; Zhang, Q.; Zhao, Q.; Yu, W.; Chang, J. Synthesis of 2-Imino-1, 3, 4-thiadiazoles from Hydrazides and Isothiocyanates via Sequential Oxidation and P (NMe2) 3-Mediated Annulation Reactions. Organic Letters 2020, 21,210-213, https://doi.org/10.1021/acs.orglett.0c01393

25. Cheng, W.; Shang, R.; Zhao, B.; Xing, W.; Fu, Y. Isonicotinate ester catalyzed decarboxylative borylation of (hetero) aryl and alkenyl carboxylic acids through N-hydroxyphthalimide esters. Organic letters 2017, 19, 4291-4294, https://doi.org/10.1021/acs.orglett.7b01950.

26. Chen, X.; Xiao, X.; Sun, H.; Li, Y.; Cao, H.; Zhang, X.; Lian, Z, Yang, S. Transition-Metal-Catalyzed Transformation of Sulfonates via S-O Bond Cleavage: Synthesis of Alkyl Aryl Ether and Diaryl Ether. Organic letters 2019, 21, 8879-8883, https://doi.org/10.1021/acs.orglett.9b02858.

27. Ma, X.; Song, Q. Tert-Butyl Nitrite Mediated Synthesis of Fluorinated O-Alkyloxime Ether Derivatives. Organic letters 2019, 21, 7375-7379, https://doi.org/10.1021/acs.orglett.9b02689.

28. Chavan, S.; Kadam, A.; Lasonkar, P.; Gonnade, R. Synthesis of 3-Azidopiperidine Skeleton Employing Ceric Ammonium Nitrate (CAN)-Mediated Regioselective Azidoalkoxylation of Enol Ether: Total Synthesis of D2 Receptor Agonist ( \pm )-Quinagolide. Organic letters 2018, 20, 7011-7014, https://doi.org/10.1021/acs.orglett.8b02900.

29. Lauro, F.-V.; Francisco, D.C.; Maria, L.-R.; Rolando, G.-M.; Marcela, R.-N.; Virginia, M.-A.; Alejandra, G.-E.E.; Yaritza, B.-B.; Yazmin, O.-A. Design and synthesis of a bismethylsulfanyl-steroid-azetyl butanol derivative from 2-nitroestradiol. Journal of Heterocyclic Chemistry 2020, 57, 1737-1747, https://doi.org/10.1002/jhet.3899.

30. Zengin, G.; Huffman, J. Naphthyl ester synthesis using 1, 3-dicyclohexylcarbodiimide. Synthesis 2004, 12, 1932-1934, https://doi.org/10.1055/s-2004-829158. 
31. Chen, C.; Chien, C.; Su, C. Preparation of acyl fluorides with hydrogen fluoride-pyridine and 1, 3dicyclohexylcarbodiimide. Journal of fluorine chemistry 2002, 115, 75-77, https://doi.org/10.1016/S00221139(02)00004-0.

32. Rafaniello, A.; Rizzacasa, M. Total Synthesis of (+)-Trachyspic Acid 19-n-Butyl Ester. Organic Letters 2020, 22, 1972-1975, https://doi.org/10.1021/acs.orglett.0c00319.

33. Abe, M.; Picard, B.; De Paolis, M. Convergent Synthesis of 2-Oxazolone-4-carboxylates Esters by Reaction of Aldehydes with Ambivalent N-Cbz- $\alpha$-Tosylglycinate Ester. Organic Letters 2020, 22, 4864-4867, https://doi.org/10.1021/acs.orglett.0c01703.

34. Figueroa-Valverde, L.; Diaz-Cedillo, F.; García-Cervera, E.; Pool-Gómez, E.; López-Ramos, M. Design and Synthesis of N-[2-(2, 3-dimethoxy-strychnidin-10-ylidenamino)-ethyl]-succinamic acid 4-allyl-2-methoxyphenyl ester. Bulgarian Chemical Communications 2013, 45, 71-76.

35. Müller, T. Intramolecular catalytic addition of amines to alkynes. Tetrahedron letters 1998, 39, 5961-5962, https://doi.org/10.1016/S0040-4039(98)01217-9.

36. Crawley, M.; Goljer, I.; Jenkins, D.; Mehlmann, J.; Nogle, L.; Dooley, R.; Mahaney, P. Regioselective synthesis of substituted pyrroles: efficient palladium-catalyzed cyclization of internal alkynes and 2-amino3-iodoacrylate derivatives. Organic Letters 2006, 8, 5837-5840, https://doi.org/10.1021/o1062424p.

37. Zhou, L.; Shuai, Q.; Jiang, H.; Li, C. Copper-Catalyzed Amine-Alkyne-Alkyne Addition Reaction: An Efficient Method For the Synthesis of $\gamma, \delta$-Alkynyl- $\beta$-amino Acid Derivatives. Chemistry-A European Journal 2009, 15, 11668-11674, https://doi.org/10.1002/chem.200901416.

38. Lo, V.; Liu, Y.; Wong, M.; Che, C. Gold (III) salen complex-catalyzed synthesis of propargylamines via a three-component coupling reaction. Organic letters 2006, 8, 1529-1532, https://doi.org/10.1021/ol0528641.

39. Zindo, F.; Malan, S.; Omoruyi, S.; Enogieru, A.; Ekpo, O.; Joubert, J. Design, synthesis and evaluation of pentacycloundecane and hexacycloundecane propargylamine derivatives as multifunctional neuroprotective agents. European Journal of Medicinal Chemistry 2019, 163, 83-94, https://doi.org/10.1016/j.ejmech.2018.11.051.

40. Gaieb, Z.; Parks, C.D.; Chiu, M.; Yang, H.; Shao, C.; Walters, W.P.; Lambert, M.H.; Nevins, N.; Bembenek, S.D.; Ameriks, M.K.; Mirzadegan, T.; Burley, S.K.; Amaro, R.E.; Gilson, M.K. T. D3R Grand Challenge 3: blind prediction of protein-ligand poses and affinity rankings. Journal of computer-aided molecular design 2019, 33, 1-18, https://doi.org/10.1007/s10822-018-0180-4.

41. Li, J.; Fu, A.; Zhang, L. An overview of scoring functions used for protein-ligand interactions in molecular docking. Interdisciplinary Sciences: Computational Life Sciences 2019, 1-9.

42. Mathian, A.; Mahevas, M.; Rohmer, J.; Roumier, M.; Cohen-Aubart, F.; Amador-Borrero, B.; Barrelet, A.; Chauvet, C.; Chazal, T.; Delahousse, M.; Devaux, M.; Euvrard, R.; Fadlallah, J.; Florens, N.; Haroche, J.; Hié, M.; Juillard, L.; Lhote, R.; Maillet, T.; Richard-Colmant, G.; Palluy, J.B.; Pha, M.; Perard, L.; Remy, P.; Rivière, E.; Sène, D.; Sève, P.; Morélot-Panzini, C.; Viallard, J.F.; Virot, J.S.; Benameur, N.; Zahr, N.; Yssel, H.; Godeau, B.; Amoura, Z. Clinical course of coronavirus disease 2019 (COVID-19) in a series of 17 patients with systemic lupus erythematosus under long-term treatment with hydroxychloroquine. Annals of the Rheumatic Diseases 2020, 79, 837-839. 